\title{
Late Cretaceous basin development of the southern Danish Central Graben
}

\author{
Finn Jakobsen and Claus Andersen
}

The Danish oil and gas production mainly comes from fields with chalk reservoirs of Late Cretaceous (Maastrichtian) and early Paleocene (Danian) ages located in the southern part of the Danish Central Graben in the North Sea. The area is mature with respect to exploration with most chalk fields located in structural traps known since the 1970s. However, the discovery by Mærsk Oil and Gas A/S of the large nonstructurally and dynamically trapped oil accumulation of the Halfdan Field in 1999 north-west of the Dan Field (e.g. Albrechtsen et al. 2001) triggered renewed exploration interest. This led to acquisition of new high quality 3-D seismic data that considerably enhanced imaging of different depositional features within the Chalk Group. Parallel to the endeavours by the operator to locate additional non-structural traps in porous chalk, the Geological Survey of Denmark and Greenland took advantage of the new data to unravel basin development by combining 3-D seismic interpretation of a large number of seismic markers, well log correlations and 2-D seismic inversion for prediction of the distribution of porous intervals in the Chalk Group. Part of this study is presented by Abramovitz et al. (in press). In the present paper we focus on aspects of the general structural development during the Late Cretaceous as illustrated by semi-regional time-isochore maps. The Chalk Group has been divided into two seismically mappable units (a Cenomanian-Campanian lower Chalk Unit and a Maastrichtian-Danian upper Chalk Unit) separated by a distinct basin-wide unconformity.

\section{Study area and database}

The mapped area comprises the Southern Salt Dome Province located in the southern part of the Danish Central Graben and adjacent parts of the Ringkøbing-Fyn High (Fig. 1). The seismic database used involves three separate 3-D data sets. The bulk of the area is covered by the 1150 $\mathrm{km}^{2}$ Kraka Extension survey, which was acquired by Mærsk in 2000. To the south and east it is supplemented by data belonging to the Fugro multi-client Entenschnabel 2002 survey and to the north-east by part of the Mærsk Contiguous Area 3-D from 1995. In addition, data from smaller surveys of different vintages were used in order to cover parts of the Coffee Soil Fault that separates the graben area from the platform.

\section{Geological setting}

Deposition of the Upper Cretaceous - Danian Chalk Group in the study area took place during a phase of regional postrift subsidence following Late Jurassic rifting. This period was marked by high sea level, high seawater temperatures and a peak in production of organic matter. The Late Cretaceous regional subsidence was modified by movements of Zechstein salt and punctuated by widespread inversion in the form of compression along old extensional fault trends, resulting in flexuring and folding of basin infill (Vejbæk \& Andersen 2002). This resulted in the development of areas with bathymetric elevations and formation of local depocentres in the intervening lows. The structural movements gave rise to a number of unconformities easily recognised as truncation and onlap surfaces on seismic profiles and to stratigraphic hiatuses in wells.

The chalk in the area is pelagic in origin and formed from settling of calcareous nannoplankton remains (coccoliths) and it consists generally of 95-99\% calcite. After deposition the pelagic chalk was subjected to redistribution

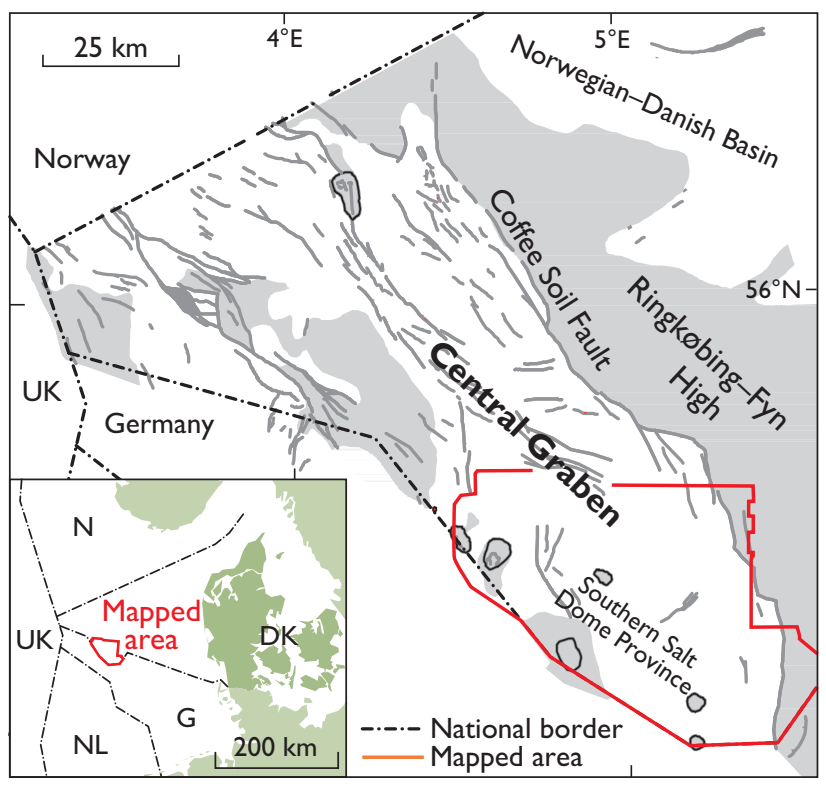

Fig. 1. Map of the Danish Central Graben region, showing the major structural elements and the location of the study area. 


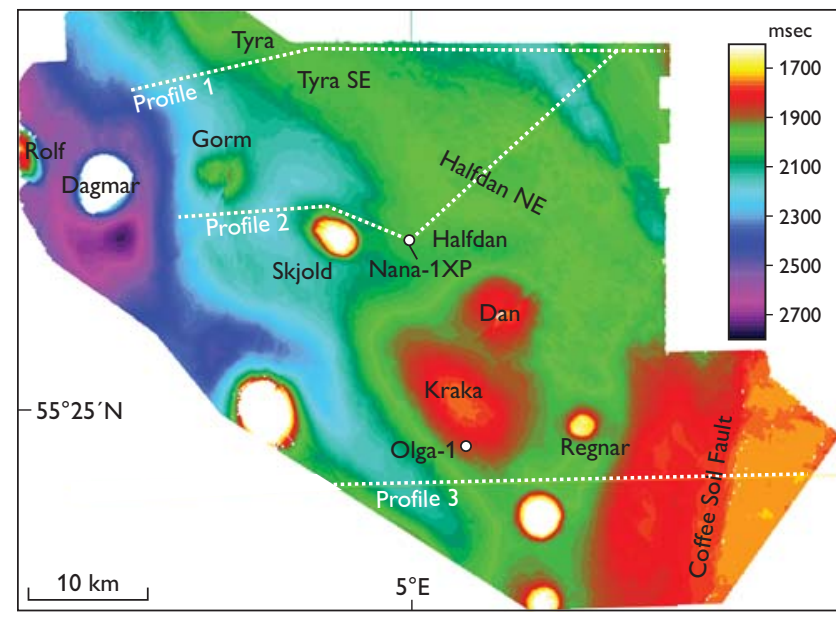

Fig. 2. Time-structure map of the Top Chalk Group with location of producing chalk fields, profiles and wells mentioned in the text. Contours on the shallow salt diapirs with thin chalk are not shown.

by various processes. These include downslope mass-flow movements arising from slope instability caused by syndepositional tectonic movements, or along-slope bottom currents that modified the seafloor forming channels, drifts, ridges and mounds. The interaction of downslope and along-slope processes has been demonstrated by Esmerode et al. (2008) in the lower part of the chalk section in the area immediately to the north of the study area.

The overall structural style is illustrated by a timestructure map of the Top Chalk Group (Fig. 2) and a timeisochore map of the total Chalk Group (Fig. 3). The latter shows very large thickness variations from less than $100 \mathrm{msec}$ $(<c .200 \mathrm{~m})$ on top of salt diapirs up to $650 \mathrm{msec}(c .1300 \mathrm{~m})$ in the rim-syncline east of the Dagmar Field. Reduced thicknesses have been mapped over the Dan and Kraka structures, which are caused by growth of underlying salt pillows. On the NNW-SSE-trending 'Gorm-Lola Ridge' extending southwards from the Gorm Field, the thinning of the chalk is caused by a combination of halokinesis and structural inversion. The asymmetric, NW-SE-trending 'Igor-Emma Ridge' with less than $100 \mathrm{msec}$ of chalk on its central part is located along the Coffee Soil Fault. The total chalk thickness is much larger on the stable Ringkøbing-Fyn High than on the adjacent inverted part of the graben.

The time-structure map of Fig. 2 shows the results of the Late Cretaceous tectonic movements combined with the effects of Cenozoic continued inversion/subsidence concentrated in the former graben area and halokinesis. Structural inversion affecting the Top Chalk Group surface is less pronounced and is restricted to the development of the centrally located, gentle, NW-SE-orientated 'Tyra-Igor Ridge' trapping the Tyra, Tyra SE and Halfdan NE gas accumulations.

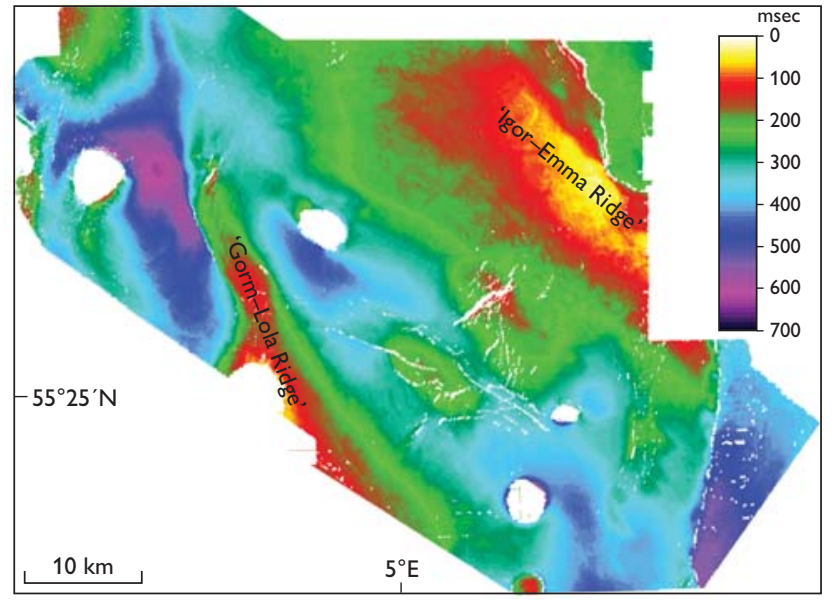

Fig. 3. Time-isochore map of the total Chalk Group with names of major inversion ridges indicated. Chalk Group isochores over the salt diapirs are not shown.

The large, dynamically trapped Halfdan oilfield is located on the south-western flank of this ridge.

\section{Basin development}

In modern 3-D seismic data, the Chalk Group is often characterised by discontinuous reflection patterns indicating spatial variations in lithology and depositional mode, and it is possible to identify and map a number of unconformities. The most prominent is here termed the Top Hod Unconformity (Fig. 4), which is generally expressed as a strong positive reflection. The unconformity divides the Chalk Group into a lower part comprising the Hod, Blodøks and Hidra Formations and an upper part comprising the Ekofisk and Tor Formations using the standard lithostratigraphic nomenclature for the Central North Sea (Surlyk et al. 2003). New palaeontological age determinations of the Olga-1x well, which is located on the flank of the Kraka structure, suggest that the unconformity here is of latest Campanian to early Maastrichtian age (Abramovitz et al. in press).

The seismic profiles in Fig. 4 are selected to illustrate reflection patterns and highlight aspects of the basin development. The northern profile in Fig. $4 \mathrm{~A}$ crosses the gentle 'Tyra-Igor Ridge' that was mainly formed by inversion postdating chalk deposition. Several generations of channel-like features cut into the Top Hod Unconformity. Furthermore, the lower part of the chalk is extensively disturbed on the eastern flank. Esmerode et al. (2008) interpreted similar features as formed by interactions between downslope mass movements (slumps and slides) and along-slope currents. The uppermost part of the chalk is draped and rather uniform in thickness suggesting reduction in earlier bathymetric relief. 
A
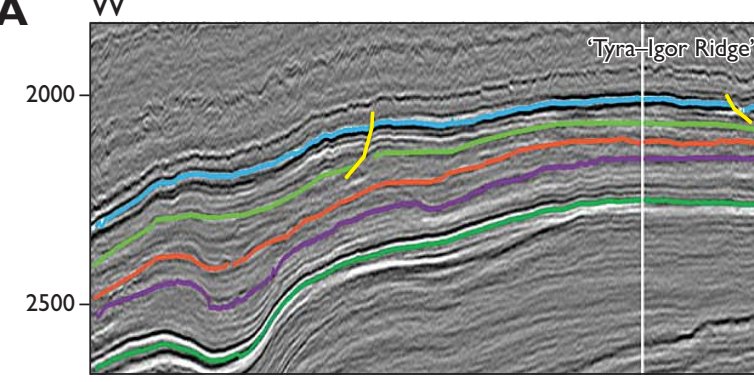

B W

Nana-1XP

NE

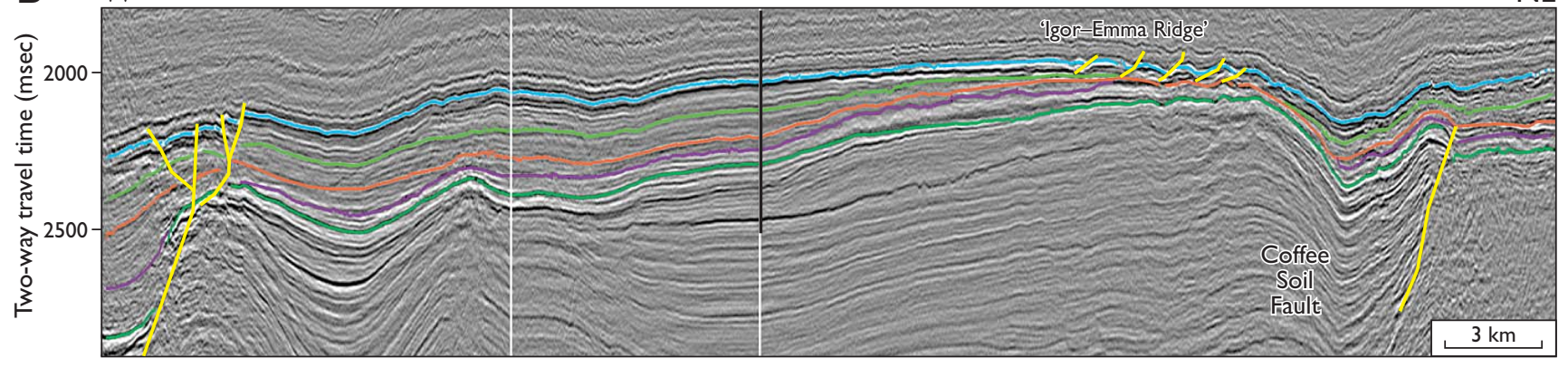

C

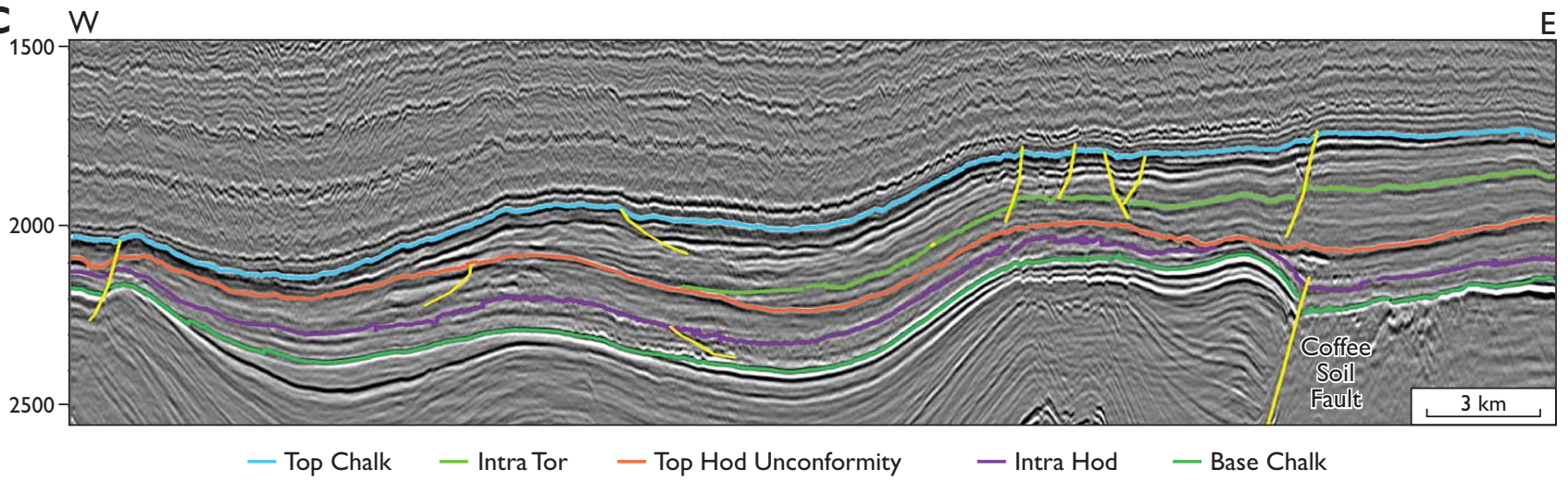

Fig. 4. A: Profile 1 crosses the gentle 'Tyra-Igor Ridge' mainly formed by inversion post-dating chalk deposition. Several generations of channel-like features cut into the Top Hod Unconformity. B: Profile 2 illustrates the asymmetric 'Igor-Emma Ridge' inversion anticline. The anticline is a result of both intra-chalk and post-chalk compression movements and developed with a steep north-eastern limb adjacent to the reversed Coffee Soil Fault. C: Profile 3 is located in the southern part of the study area that is characterised by an asymmetric basin development with an eastward shift in depocentres. Yellow lines show faults. For location of the profiles see Fig. 2.

The Top Chalk Group surface on the eastern flank is cut by low-angle listric faults, indicating early post-Danian slumping of poorly consolidated chalk caused by renewed inversion along the ridge.

Figure 4B illustrates the asymmetric 'Igor-Emma Ridge' inversion anticline trapping the Halfdan NE gasfield found in Danian chalk. The anticline is a result of both intra-chalk and post-chalk compression movements and developed with a steep north-eastern limb adjacent to the reversed Coffee Soil Fault. The lower part of the chalk is deeply eroded at the crest and the Top Hod Unconformity merges with older truncation surfaces. The Tor Formation above onlaps the western flank. The thinning and condensation of the Tor
Formation is associated with deterioration of reservoir properties in the Upper Maastrichtian Tor Formation chalk arresting up-dip oil migration from the Halfdan Field, which was discovered from the Nana-1XP vertical well.

Figure $4 \mathrm{C}$ shows a W-E profile that crosses the Coffee Soil Fault. The profile is located in the southern part of the study area that is characterised by an asymmetric basin development with thick lower chalk below the Top Hod Unconformity in the Central Graben area to the west, and an eastward shift of depocentre above. The lower part of the Tor Formation is thick on the Ringkøbing-Fyn High. It gradually onlaps the unconformity indicating significant variations in time span of missing sections across this surface. 

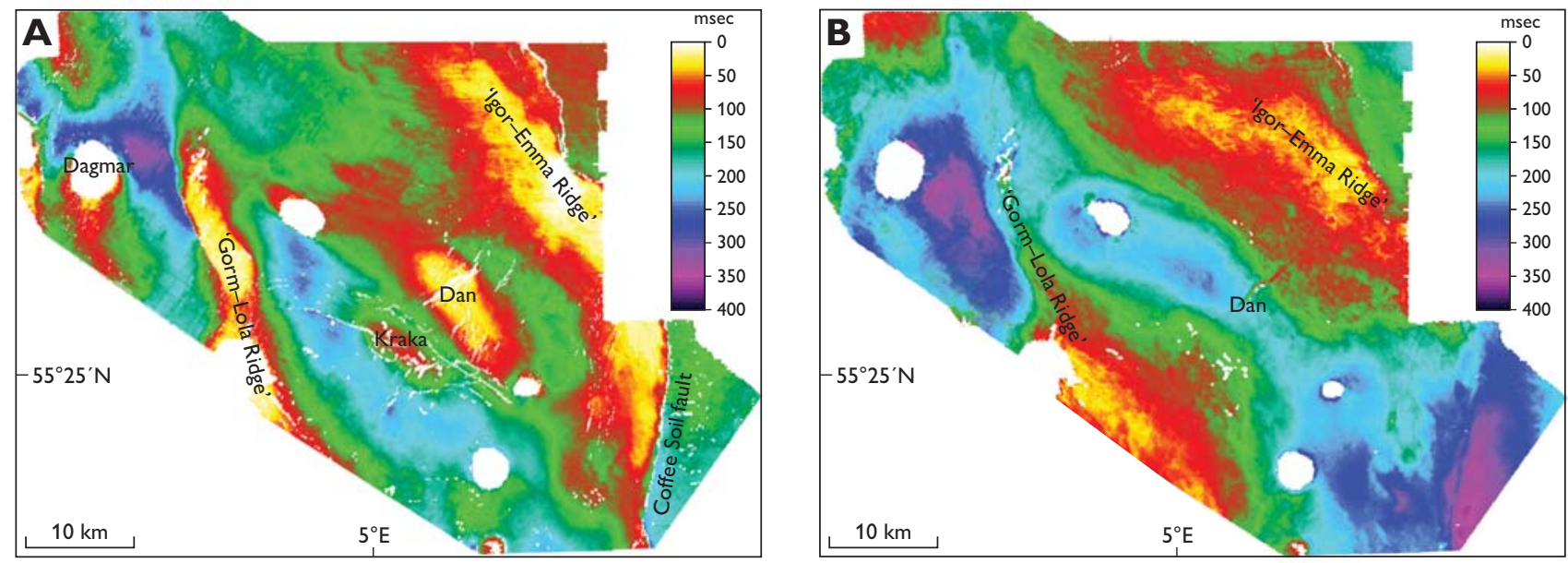

Fig. 5. Time-isochore maps. A: Lower Chalk Group interval. B: Upper Chalk Group interval. The isochores show shift of depocentres during the Late Cretaceous in a north-eastward direction.

The general basin development during the Late Cretaceous and Danian can further be visualised by comparing the semi-regional time-isochore maps of the lower and upper parts of the Chalk Group separated by the Top Hod Unconformity. The Lower Chalk Group interval shows large thickness variations with the main depocentre (up to $350 \mathrm{msec}$ ) found in the rim-syncline north and east of the Dagmar salt diapir (Fig. 5A). The 'Gorm-Lola Ridge' separates it from a NW-SE-orientated depocentre that covers the southern flank of the Kraka structure. The Lower Chalk Group interval is also thin over the Dan Field area, indicating structural growth caused by underlying halokinetic movements. A conspicuous feature is the asymmetric 'Igor-Emma Ridge' inversion anticline along the reversed Coffee Soil Fault where the lower chalk is thin and even seismically absent in the crestal part.

The time-isochore map of the Upper Chalk Group interval (Fig. 5B) shows more gradual thickness variations. The most notable difference between the two units is the northeastward shift and widening of the NW-SE-orientated depocentre. At the Dan Field only an insignificant thinning of the interval is mapped, which shows that halokinetic movements waned here during the Maastrichtian and $\mathrm{Da}$ nian. The expression of both the 'Gorm-Lola Ridge' and the 'Igor-Emma Ridge' is less distinct. The latter is confined to the northern part of the mapped area and orientated slightly obliquely to the NNW-SSE-trending segments of the Coffee Soil Fault Zone.

By using a simple two-fold subdivision of the Chalk Group, the present paper illustrates the dynamic basin de- velopment with spatial changes in subsidence patterns and structural growth caused by halokinesis and structural inversion. A more detailed analysis of the basin development with an additional subdivision of the Chalk Group is in progress in combination with mapping of sedimentary features. Based on the close relationship between erosion, re-deposition (deposition of reservoir chalk) and structural development, the basin development is used as a guide for prediction of hitherto unrecognised reservoir intervals.

\section{References}

Abramovitz, T., Andersen, C., Jakobsen, F.C., Kristensen, L. \& Sheldon, E. (in press): 3-D seismic mapping and porosity variation of intra-chalk units in the southern Danish North Sea. In: Vining, B.A. (ed): Petroleum geology: from mature basins to new frontiers. Proceedings of the 7th Petroleum Geology Conference. London: Geological Society.

Albrechtsen, T., Andersen, S. J., Dons, T., Engstrøm, F., Jørgensen, O. \& Sørensen, F.W. 2001: Halfdan: Developing non-structurally trapped oil in North Sea chalk. Paper SPE 71322. New Orleans, Louisiana: Society of Petroleum Engineers Annual Technical Conference and Exhibition.

Esmerode, E.V., Lykke-Andersen, H. \& Surlyk, F. 2008: Interaction between bottom currents and slope failure in the Late Cretaceous of the southern Danish Central Graben, North Sea. Journal of the Geological Society (London) 165, 55-72.

Surlyk, F., Dons, T., Clausen, C.K. \& Higham, J. 2003: Upper Cretaceous. In: Evans, D. et al. (eds and co-ordinators): The millennium atlas: petroleum geology of central and northern North Sea, 213-233. London: Geological Society.

Vejbæk, O.V. \& Andersen, C. 2002: Post mid-Cretaceous inversion tectonics in the Danish Central Graben - regionally synchronous tectonic events? Bulletin of the Geological Society of Denmark 49, 129-144.

\footnotetext{
Authors' address

Geological Survey of Denmark and Greenland, Øster Voldgade 10, DK-1350 Copenhagen K, Denmark. E-mail:fj@geus.dk
} 